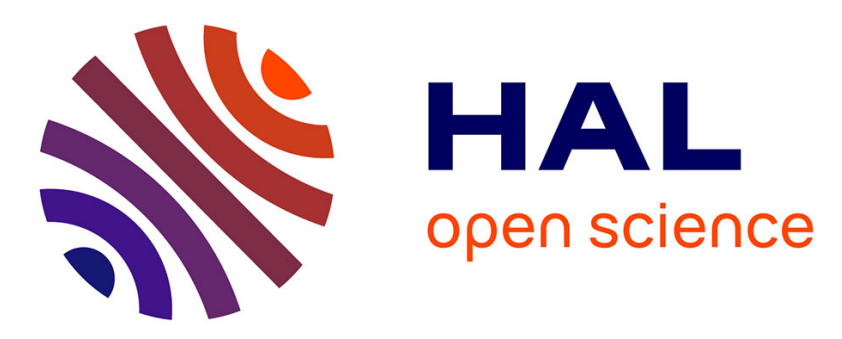

\title{
International standardized procedures forin vivo evaluation of multi-walled carbon nanotube toxicity in water
}

\author{
Florence Mouchet, Christian Gancet, Emmanuel Flahaut, Eric Pinelli, \\ Jean-charles Boutonnet, Laury Gauthier
}

\section{To cite this version:}

Florence Mouchet, Christian Gancet, Emmanuel Flahaut, Eric Pinelli, Jean-charles Boutonnet, et al.. International standardized procedures forin vivo evaluation of multi-walled carbon nanotube toxicity in water. Toxicological and Environmental Chemistry, 2016, vol. 98 (n 8), pp. 829-847. 10.1080/02772248.2015.1133818 . hal-01475094

\author{
HAL Id: hal-01475094 \\ https://hal.science/hal-01475094
}

Submitted on 23 Feb 2017

HAL is a multi-disciplinary open access archive for the deposit and dissemination of scientific research documents, whether they are published or not. The documents may come from teaching and research institutions in France or abroad, or from public or private research centers.
L'archive ouverte pluridisciplinaire HAL, est destinée au dépôt et à la diffusion de documents scientifiques de niveau recherche, publiés ou non, émanant des établissements d'enseignement et de recherche français ou étrangers, des laboratoires publics ou privés. 


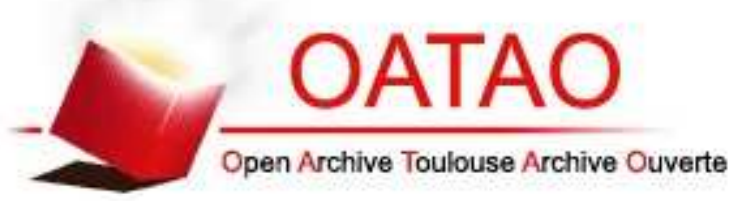

\section{Open Archive TOULOUSE Archive Ouverte (OATAO)}

OATAO is an open access repository that collects the work of Toulouse researchers and makes it freely available over the web where possible.

This is an author-deposited version published in : http://oatao.univ-toulouse.fr/ Eprints ID : 16788

To link to this article : DOI : 10.1080/02772248.2015.1133818

URL : http://dx.doi.org/10.1080/02772248.2015.1133818

To cite this version : Mouchet, Florence and Gancet, Christian and Flahaut, Emmanuel and Pinelli, Eric and Boutonnet, Jean-Charles and Gauthier, Laury International standardized procedures forin vivoevaluation of multi-walled carbon nanotube toxicity in water. (2016) Toxicological \& Environmental Chemistry, vol. $98\left(n^{\circ} 8\right)$. pp. 829-847. ISSN 0277-2248

Any correspondence concerning this service should be sent to the repository administrator: staff-oatao@ listes-diff.inp-toulouse.fr 


\title{
International standardized procedures for in vivo evaluation of multi-walled carbon nanotube toxicity in water
}

\author{
Florence Mouchet ${ }^{a, b, c}$, Christian Gancet ${ }^{c, d}$, Emmanuel Flahaut ${ }^{c, e}$, Eric Pinelli ${ }^{a, b, c}$, \\ Jean-Charles Boutonnet ${ }^{c, f}$ and Laury Gauthier ${ }^{a, b, c}$ \\ ${ }^{a} E$ EcoLab (Laboratoire d'Ecologie Fonctionnelle et Environnement), INP, UPS, Université de Toulouse, Tolosan, \\ France; ${ }^{b}$ EcoLab, CNRS, Tolosan, France; ${ }^{c}$ Laboratoire Commun NAUTILE (CNRS-UPS-INPT-ARKEMA

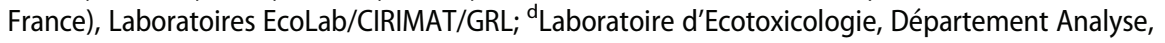

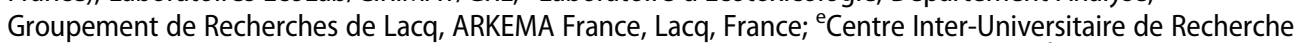 \\ et d'Ingénierie des Matériaux - CIRIMAT, UMR UPS INPT CNRS 5085, Toulouse, France; 'Direction Sécurité \\ Environnement Produits, ARKEMA France, Colombes, France
}

\begin{abstract}
The classical approach in ecotoxicological evaluation of chemical substances consists of conducting standardized bioassays on organism models. In this work, the potential impact of industrial multiwalled carbon nanotubes was investigated by ecotoxicological standardized procedures using aquatic organisms of different trophic levels, namely bacteria, green algae, invertebrates, fish, and amphibians. The results indicated (1) inhibition of growth in amphibians at $50 \mathrm{mg} \mathrm{L}^{-1}$ and higher, and (2) no effects on daphnia and fish up to $100 \mathrm{mg} \mathrm{L}^{-1}$. With the exception of algae (for which Fe deficiency is measured), it seems that the observed toxicity may be due to physiological effects in relation to the ingestion of carbon nanotubes not necessarily related to their intrinsic effects.
\end{abstract}

\section{KEYWORDS}

Multi-walled carbon nanotubes; ecotoxicity; standardized bioassays; bacteria; algae; fish; amphibians

\section{Introduction}

The publication of Iijima (1991) generated unprecedented interest in the world of carbon nanostructures and led to an exponential growth in research on carbon nanotechnology. Carbon nanotubes (CNTs) can be described as graphene sheets rolled up to form cylinders that are closed at both ends. There are two main types, i.e. single-walled CNTs (SWNTs) and multi-walled CNTs (MWNTs). They have remarkable physical, i.e. mechanical, electric, and thermal and chemical properties (inertness, stability), making them a material of choice for polymer composites, electromagnetic shields, super capacitors, gas including hydrogen storage devices, batteries, structural composites, or medical applications (Eklund et al. 2007), especially of MWNTs for biomedical engineering, used in biosensors, as vehicles for drug delivery, and in gene therapy (Kostarelos, Bianco, and Prato 2009).

Most likely, during production and use, some quantities will get into the environment, especially the aquatic compartment. Even if toxicological data are available, obtained 
most often with in vitro systems (Guadagnini et al. 2013) and with animal models (Van der Zande et al. 2011), nevertheless ecotoxicological exposure and effect data are necessary for understanding the potential hazards these new carbon-based materials may pose for the environment. As new substances, CNTs require registration under the Toxic Substances Control Act in the USA and in the European Union according to REACh (Registration, Evaluation, Authorization and Restriction of Chemicals) regulations (EU 2008). Some (eco)toxicological and environmental properties of SWNTs and MWNTs are listed in the report ENV/JM/MONO 13/REV (2008), but more is required for the proper evaluation of the potential ecotoxicity of CNTs. Aquatic ecotoxicity assessment of CNTs is a challenge since tests have been developed for water-soluble chemical compounds. Nevertheless, standard environmental hazard assessment is generally appropriate for nanoecotoxicological research (Crane et al. 2008), especially using the test battery concept (Kahru et al. 2008; Blaise et al. 2008) in order to accumulate knowledge about their ecotoxicity (Kahru and Dubourguier 2011) toward a wider range of biological species providing valuable insight into likely exposure scenarios (Zhao and Liu 2012).

The aim of the present work is to contribute to the ecotoxicological assessment of the potential impact of MWNTs as an example of industrial CNTs in aquatic organisms belonging to different trophic levels by carrying out ecotoxicological standardized procedures. The selected species were decomposers (bacteria), primary producers (photosynthetic green algae, Pseudokirchneriella subcapitata), primary consumers (invertebrates Daphnia magna), and secondary consumers (vertebrate fish and amphibians, Danio rerio and Xenopus laevis).

\section{Materials and methods}

\section{MWNTs preparation of suspensions}

MWNT (Graphistrength ${ }^{\oplus} \mathrm{C} 100$, Arkema, Colombes, France) suspensions in ultrapure water were prepared by sonication for $10 \mathrm{~min}$ at $45 \mathrm{kHz}, 80 \mathrm{~W}$ (USC 300T, VWR, Fontenay sous Bois, France) just before each bioassay. The physical characteristics and transmission electron microscopic observations of the MWNTs were previously described by Mouchet et al. (2010). Figure 1 displays scanning electron micrographs of MWNTs.

\section{Biological bioassays}

\section{Activated sludge respiration inhibition test, OECD (1984) Guideline 209}

The inoculum was activated sludge of a small biological domestic wastewater treatment plant (Abidos, France). MWNTs were studied at 500 and $5000 \mathrm{mg} \mathrm{L}^{-1}$. Dissolved oxygen concentrations were determined with an oxygen electrode (Stirrox G, WTW, Weilheim, Germany) and meter (OXI 538, WTW). The inhibitory effect was expressed as percentage of the mean respiration rate of two controls, calculated from the recorder trace as $\mathrm{mg} \mathrm{O}_{2} \mathrm{~L}^{-1} \mathrm{~h}^{-1}$ over a period of $10 \mathrm{~min}$. The inhibition was expressed as percentage relative to the mean of the respiration rates in two controls: \% inhibition $=\left[1-\left(2 R_{\mathrm{s}} /\left(R_{\mathrm{c} 1}+R_{\mathrm{c} 2}\right)\right)\right] \times 100$, where $R_{\mathrm{s}}$ is the oxygen consumption rate at the tested concentration of test substance, and $R_{\mathrm{c} 1}$ and $R_{\mathrm{c} 2}$ are the oxygen consumption rates for controls 1 and 2 . The sensitivity of the test system and the method were evaluated with 3,5-dichlorophenol. 

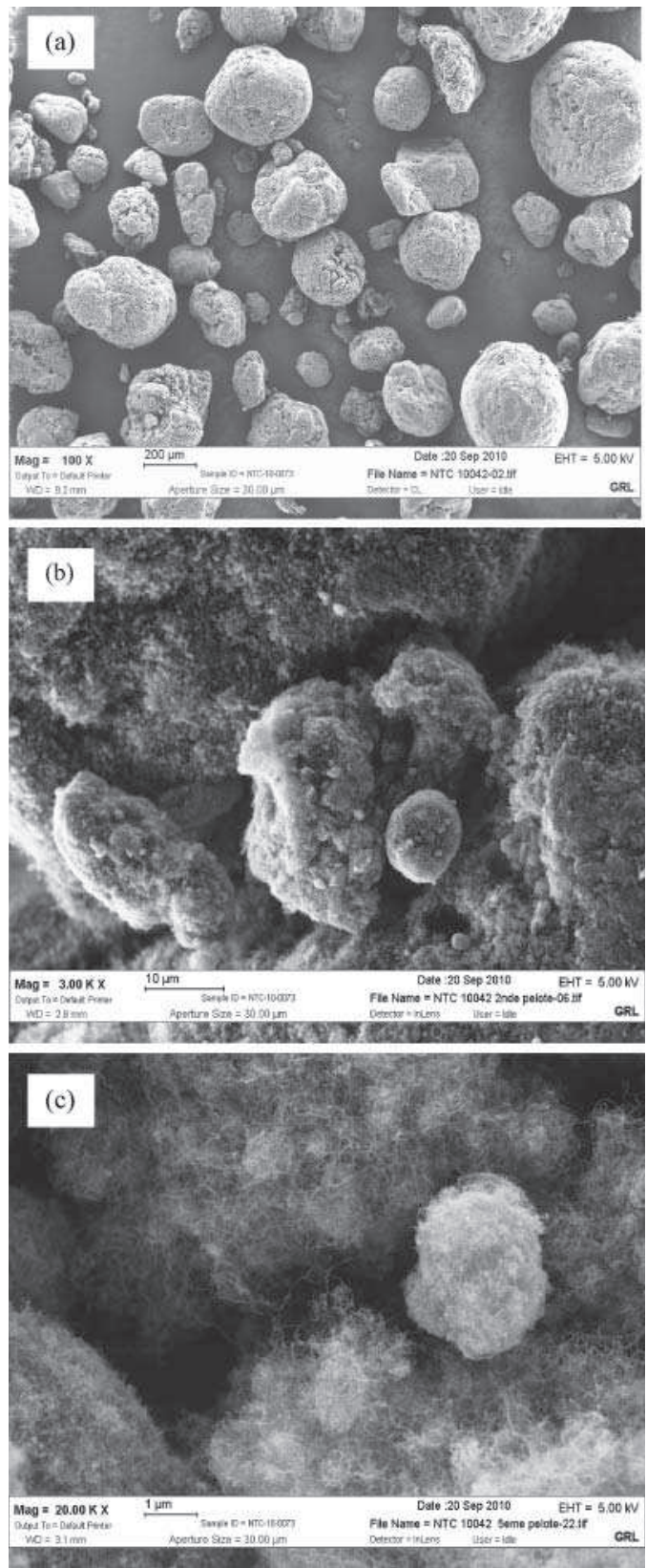

Figure 1. Scanning electron microscopy observations of MWNTs, raw MWNTs from the same sample are observable in balls at different magnifications: (a) $100 \mathrm{X}$, (b) $3000 \mathrm{X}$ and (c) 20,000 X.

Algal growth inhibition test (P. subcapitata), OECD (2006) Guideline 201

P. subcapitata (CCAP 278/4 stock) was obtained from the Culture Centre of Algae and Protozoa (Ambleside, UK). The cell density (measured fluorescence, Cytofluor 2350, Millipore, Molsheim, France) for the preliminary test was $1.21 \times 10^{6}$ cells $\mathrm{mL}^{-1}$, and for the definitive test, $1.09 \times 10^{6}$ cells $\mathrm{mL}^{-1}$. Algae were exposed under static conditions over 
a time period of $72 \mathrm{~h}$ to MWNTs dispersed in water (EN ISO 8692, 2004) at (1) 100, 50, $10,5,1$, and $0 \mathrm{mg} \mathrm{L}^{-1}$ in the preliminary test, and (2) $1000,500,230,105,48,22,10$, and $0 \mathrm{mg} \mathrm{L}^{-1}$ for the definitive test. The MWNT concentrations resulting in $0 \%$ and $100 \%$ of the uninhibited cell growth rate, and growth rate inhibition causing a $50 \%$ reduction in biomass $\left(\mathrm{E}_{\mathrm{b}} \mathrm{C}_{50}\right)$ within $72 \mathrm{~h}\left(\mathrm{E}_{\mathrm{b}} \mathrm{C}_{50}-72 \mathrm{~h}\right)$ and in growth rate $\left(\mathrm{E}_{\mathrm{r}} \mathrm{C}_{50}-72 \mathrm{~h}\right)$ were estimated. The sensitivity of the test system and the method were evaluated by performing an algal growth inhibition test on $\mathrm{K}_{2} \mathrm{Cr}_{2} \mathrm{O}_{7}$ (Sigma, Lyon, France). The growth inhibition data were analyzed using an Excel sheet to calculate the effective concentration $\left(\mathrm{EC}_{50}\right.$ value) and the 95\% confidence interval. Probit analysis was used to calculate the 24-, 48-, and 72-h $\mathrm{EC}_{50}$ values. The no-observed effect concentration (NOEC), the highest tested concentration at which no significant inhibition of growth is observed relative to the control, was estimated by Dunnett's test. Values of $\mathrm{pH}$ (345 pH meter, Mettler Toledo, Viroflay, France) and dissolved $\mathrm{O}_{2}$ (OXI 538 oxymeter, WTW) were measured.

Analytic complementary experiments have been carried out to study the ecotoxicological response of algae in relation to a potential deficiency of ionic metallic species, with the well-known property of CNTs to adsorb ionic species (Li et al. 2009; Stafiej and Pyrzynska 2007). B, Mn, Fe, Co, Ni, Cu, Zn, and Mo were measured in algal media (water dilution) with and without MWNTs after filtration $(0.45 \mu \mathrm{m}$ to remove most of MWNTs) by ICP-MS (ICP-MS 7500, Agilent, Les Ulis, France) at the end of the experiment. Detection limits were $1 \mu \mathrm{g} \mathrm{L}^{-1}$. Metal traces were measured in water dilution alone, with and without Fe. The algal growth inhibition test was carried out with and without Fe to check the effect of iron deficiency.

\section{D. magna acute immobilization test, OECD (2004) Guideline 202}

D. magna Straus (Cladocera, Crustacea), clone 5 and clone A, were from stock breeding in the laboratory reared in Volvic ${ }^{\otimes}$ water added of $0.1 \mathrm{~mL} \mathrm{~L}^{-1} \mathrm{~B}_{12}$ solution $\left(1 \mu \mathrm{g} \mathrm{L} \mathrm{L}^{-1}\right.$, Alfa Aesar, Kandel, Germany), $0.1 \mathrm{~mL} \mathrm{~L}{ }^{-1} \mathrm{Na}_{2} \mathrm{SeO}_{3} \cdot 5 \mathrm{H}_{2} \mathrm{O}$ solution (6.7 $\mu \mathrm{g} \mathrm{L} \mathrm{L}^{-1}$, Sigma), $1 \mathrm{~mL} \mathrm{~L}^{-1}$ solution of $\mathrm{Ca}\left(\mathrm{NO}_{3}\right)_{2} \cdot 4 \mathrm{H}_{2} \mathrm{O}\left(208 \mathrm{~g} \mathrm{~L}^{-1}\right.$, Sigma) and $\mathrm{MgCl}_{2} \cdot 6 \mathrm{H}_{2} \mathrm{O}$ (28 $\mathrm{g} \mathrm{L}^{-1}$, Sigma), and unicellular green freshwater algae (P. subcapitata and Chlorella vulgaris). A stock suspension at $100 \mathrm{mg} \mathrm{L}^{-1}$ was used to realize dilutions of 100, 50, 10, 5 , 1, and $0.1 \mathrm{mg} \mathrm{L}^{-1}$ of MWNTs in water (EN ISO 6341, 1996) for the preliminary test. In the definitive test, based on the results of the preliminary test, a limit test was performed at $100 \mathrm{mg} \mathrm{L}^{-1}$. Five D. magna aged from 6 to $24 \mathrm{~h}$ were added to each test flask. Two preliminary and four definitive test replicates were prepared for each concentration. As controls, two preliminary tests and four definitive test flasks without MWNTs were prepared under the same conditions. After 24-h incubation (definitive test), mobile $D$. magna were counted and flasks were placed back for continued incubation. At $48 \mathrm{~h}$, mobile D. magna were counted again (preliminary and definitive tests). The sensitivity of the test system and the method were evaluated every month by performing an inhibition test with $\mathrm{K}_{2} \mathrm{Cr}_{2} \mathrm{O}_{7}$ (Sigma). At $24 \mathrm{~h}$ and at the end of the 48-h test period, the actual concentrations inhibiting the mobility of daphnids by $50 \%$, i.e. $\mathrm{EC}_{50}-24 \mathrm{~h}$ and $\mathrm{EC}_{50}-48 \mathrm{~h}$, were estimated. The NOEC was estimated when possible. Dissolved $\mathrm{O}_{2}$ (OXI 538 oxymeter, WTW) and $\mathrm{pH}$ (345 pH meter, Mettler Toledo) were measured at the highest concentration and in the control at the beginning and at all concentrations, and in the control at the end of the test. 


\section{D. magna reproduction test, OECD (2008) Guideline 211}

Daphnia were exposed to MWNTs in a semi-static test from 5 to $100 \mathrm{mg} \mathrm{L}^{-1}$. Exposure water was prepared with Volvic ${ }^{\bullet}$ water complemented as follows: $0.1 \mathrm{~mL} \mathrm{~L}^{-1} \mathrm{~B}_{12}$ solution (1 $\mu \mathrm{g} \mathrm{L}^{-1}$, Alfa Aesar, Kandel, Germany), $0.1 \mathrm{~mL} \mathrm{~L}^{-1} \mathrm{Na}_{2} \mathrm{SeO}_{3} \cdot 5 \mathrm{H}_{2} \mathrm{O}$ solution $(6.7 \mu \mathrm{g}$ $\mathrm{L}^{-1}$, Sigma), $1 \mathrm{~mL} \mathrm{~L}^{-1}$ solution of $\mathrm{Ca}\left(\mathrm{NO}_{3}\right)_{2} \cdot 4 \mathrm{H}_{2} \mathrm{O}\left(208 \mathrm{~g} \mathrm{~L}^{-1}\right.$, Sigma), and $\mathrm{MgCl}_{2} \cdot 6 \mathrm{H}_{2} \mathrm{O}$ (28 $\mathrm{g} \mathrm{L}^{-1}$, Sigma). The test was performed with one Daphnia per vessel and with 10 replicates for each concentration. Ten control flasks without MWNTs were prepared under the same conditions. The positive control was with $\mathrm{K}_{2} \mathrm{Cr}_{2} \mathrm{O}_{7}$ (Sigma). For each exposure concentration, the percentage of inhibition of reproduction was recorded after 21 days. The results of the acute toxicity test were used to define the concentration range for the reproduction test. The MWNT concentrations resulting in $0 \%$ and $100 \%$ inhibition of reproduction were determined by observation, and $\mathrm{EC}_{50}$ was estimated by calculation using the HILL model (an Excel ${ }^{\circ}$ macro REGTOX http://www.normalesup.org/ $\sim$ vindimian/fr_download.html). The lowest observable effect concentration (LOEC) and NOEC were determined using Dunnett's test.

\section{Fish acute toxicity test (D. rerio), OECD (1992) Guideline 203}

The organisms used for the test were D. rerio (Teleostei, Cyprinidae), batch $\mathrm{n}^{\circ} 10 / \mathrm{Br} / 01 / 1$ supplied by Aquatrade (Saint Forgeux, France). The sensitivity of the biological reagent was checked at least once for each new batch of fish by determining the lethal concentration at $24 \mathrm{~h}\left(\mathrm{LC}_{50}-24 \mathrm{~h}\right)$ of $\mathrm{K}_{2} \mathrm{Cr}_{2} \mathrm{O}_{7}$. Fish were exposed under static conditions to 1, 35, 50 , and $100 \mathrm{mg} \mathrm{L}^{-1}$ of MWNTs dispersed in water (EN ISO 7346, 1998) for the preliminary test and to $100 \mathrm{mg} \mathrm{L}^{-1}$ for the definitive test. Two replicate test chambers were maintained for each treatment and each control group. For the range-finding test, MWNT suspensions were directly prepared for each concentration, and for the definitive test by weighing the respective amounts of MWNTs into $100 \mathrm{~mL}$ water and under adjustment to the $5 \mathrm{~L}$ in the test tanks. In both tests, the fish were considered dead if no reaction was observed when no respiratory movement was observed upon stimulation of their caudal peduncle. Visible anomalies were noted, as were any sublethal effects such as loss of balance, altered pigmentation, changes in swimming behavior, or respiratory malfunction. The dead fish were counted and removed from the aquaria. At 24, 48, and $72 \mathrm{~h}$ and at the end of the $96-\mathrm{h}$ test period, the concentrations killing $50 \%$ of the fish, i.e. $\mathrm{LC}_{50}-24,-48$, -72 and $-96 \mathrm{~h}$, were estimated. Dissolved $\mathrm{O}_{2}$ (OXI 538 oxymeter, WTW) and $\mathrm{pH}$ (345 $\mathrm{pH}$ meter, Mettler Toledo) were monitored.

\section{Amphibian (X. laevis) bioassays}

Eggs were obtained from the Ecolab laboratory. The procedure for rearing of X. laevis and breeding until they reached the development stage appropriate for experimentation - stage 50 of the development table of Nieuwkoop and Faber (Nieuwkoop and Faber 1956) - is described by Mouchet et al. (2008). MWNT dilutions were made in $20 \mathrm{~mL}$ of ultra-pure water in glass tubes, and then sonicated (Bioblock 89863, Fisher Scientific, Illkirch, France) for $5 \mathrm{~min}$ before their transfer to the exposure media. Exposure was in reconstituted water (RW), i.e. distilled tap water to which nutritive salts were added as described in ISO 21427-1 (ISO 2006). The negative control condition (NC) was RW alone. 
The first exposure was under static conditions for $96 \mathrm{~h}$. Larvae were exposed in triplicate groups of 10 animals per flask containing either RW or test media at 10,50, 100, and $500 \mathrm{mg} \mathrm{L}^{-1}$ MWNTs in RW. Each day, the number of dead larvae was counted and the lethal concentration at which mortality occurred for $50 \%$ of the animals $\left(\mathrm{LC}_{50}\right)$ was calculated. The sensitivity of the test system and the method were evaluated using $\mathrm{CdCl}_{2}$ (Sigma).

The second type of exposure was performed for $12 \mathrm{~d}$ according to ISO 21427-1 (ISO 2006) for the amphibian micronucleus test (MNT) with a daily renewal of the exposure medium. For the positive control (PC), cyclophosphamide (Sigma) in RW at $20 \mathrm{mg} \mathrm{L}^{-1}$ was used. Xenopus larvae were exposed to $0.05,0.1,0.5,1,5,10,25$, and $50 \mathrm{mg} \mathrm{L}^{-1}$ of MWNTs in RW. Larvae were exposed in groups of 20 animals in dishes containing either control media (NC and PC) or test media $\left(0.1,1,10\right.$, and $50 \mathrm{mg} \mathrm{L}^{-1}$ of raw MWNTs in RW). Acute toxicity (mortality) of larvae exposed to MWNTs was examined for $12 \mathrm{~d}$ by visual inspection and counting. Chronic toxicity, i.e. growth inhibition, was evaluated by measuring the size of each surviving larva $(n=20)$ at the beginning of exposure $\left(t_{0}\right)$ and at the end of the exposure at day $12\left(t_{12}\right)$. The measurements and statistical analyses were performed according to Mouchet et al. (2011) using a Kruskall-Wallis test followed by Dunn's test to isolate the group(s) that differ(s) from others, using a multiple comparison procedure with unpaired data versus the NC group $(\alpha<0.05)$. Graphic representations are proposed based on the growth rate calculated as mentioned in Mouchet et al. (2011).

The MNT was performed according to ISO 21427-1 (ISO 2006). At the end of $12 \mathrm{~d}$ of exposure - stage 54 (Nieuwkoop and Faber 1956) - larvae are anaesthetized by immersion in a MS222 solution ( $0.2 \mathrm{~g} \mathrm{~L}^{-1}$, Sigma) and a blood sample was obtained from each larva by cardiac puncture. The number of erythrocytes containing one micronucleus (MN) or more (micronucleated erythrocytes) was determined under a microscope in a total of 1000 erythrocytes per larva. The statistical method was described in Mouchet et al. (2008). Values of $\mathrm{pH}$ (345 $\mathrm{pH}$ meter, Mettler Toledo) were measured three times during the 12 days of exposure just before the renewal of the exposure medium $\left(\mathrm{pH}_{24 \mathrm{~h}}\right)$ and just after $\left(\mathrm{pH}_{0 \mathrm{~h}}\right)$. $\mathrm{Al}, \mathrm{Fe}$, and Mo were measured in RW with and without MWNTs after filtration $(0.45 \mu \mathrm{m}$ to remove most of MWNTs) by ICP-MS (ICP-MS 7500, Agilent).

\section{Results}

\section{Activated sludge respiration inhibition test}

The method was applied with respect to the following criteria: (1) the difference in respiration rates between the two controls was below 15\% (Table 1) and (2) $\mathrm{EC}_{50}$ of the control

Table 1. Results of respiration and inhibition rate of microorganisms of activated sludge after $3 \mathrm{~h}$ in the presence of MWNTs.

\begin{tabular}{lcccr}
\hline & \multicolumn{4}{c}{ MWNTs $\left(\mathrm{mg} \mathrm{L}^{-1}\right)$} \\
\cline { 2 - 5 } & $\mathrm{C} 1$ & $\mathrm{C} 2$ & 500 & 5000 \\
\hline $\begin{array}{l}\text { Respiration rate }\left(\mathrm{O}_{2} \mathrm{mg} \mathrm{L}^{-1} \mathrm{~h}^{-1}\right) \\
\text { \% inhibition }\end{array}$ & 52.5 & 45.0 & 54.0 & 28.0 \\
\hline
\end{tabular}

C1, C2: control 1, 2 
test with the reference 3,5-dichlorophenol was between the validity specified range of 5 and $30 \mathrm{mg} \mathrm{L}^{-1}\left(14 \mathrm{mg} \mathrm{L}^{-1}\right)$.

MWNTs did not affect the respiration rate of activated sludge in the conditions of the test up to a concentration of $500 \mathrm{mg} \mathrm{L}^{-1}$ at 54 and $28 \mathrm{mg} \mathrm{O}_{2} \mathrm{mg} \mathrm{L}^{-1} \mathrm{~h}^{-1}$, respectively, for 500 and $5000 \mathrm{mg} \mathrm{L}^{-1}$ of MWNTs. Inhibition percentage was $0 \%$ and $42.6 \%$ for 500 and $5000 \mathrm{mg} \mathrm{L}^{-1}$, respectively. $\mathrm{EC}_{50}(3 \mathrm{~h})$ was, therefore, higher than $5000 \mathrm{mg} \mathrm{L}^{-1}$.

\section{Algal growth inhibition test (P. subcapitata)}

The study was performed in compliance with the following quality criteria: (1) biomass in the control cultures increased exponentially by a factor of 102 higher than 16 within the 72-hour test period which corresponds to a specific growth rate of $0.92 \mathrm{~d}^{-1} ;(2)$ the mean coefficient of variation for section-by-section specific growth rates (days $0-1,1-2$, and $2-3$, for 72 -h tests) in the control cultures did not exceed 35\%; and (3) the coefficient of variation of average specific growth rates during the whole test period in replicate control cultures did not exceed $7 \%$.

In both tests, inhibition percentage of cell growth and growth rate increase with the increase in MWNT concentrations (Table 2). Total inhibition was observed to $500 \mathrm{mg}$ $\mathrm{L}^{-1}$ of MWNTs for the cell growth and to $1000 \mathrm{mg} \mathrm{L}^{-1}$ for the growth rate. The MWNTs concentration causing a $50 \%$ reduction in cell growth $\left(\mathrm{E}_{\mathrm{b}} \mathrm{C}_{50}\right)$ was estimated at 34 (23-47) $\mathrm{mg} \mathrm{L}^{-1}$, and the growth rate $\left(\mathrm{E}_{\mathrm{r}} \mathrm{C}_{50}\right)$ was estimated at $120(87-160) \mathrm{mg} \mathrm{L}^{-1}$. The NOEC was also estimated at $10 \mathrm{mg} \mathrm{L}^{-1}$ for the growth rate inhibition and less than $10 \mathrm{mg}$ $\mathrm{L}^{-1}$ for the cell growth. It has to be emphasized that the endpoint used for regulatory purposes is the growth rate and not the cell growth (biomass increase). It was observed that the majority of MWNT particles did not remain in suspension between the beginning and the end of the tests but gathered at the lower part of each flask. Microscopic observations confirmed that the algae appeared normal at the end of the test: The normal shape of $P$. subcapitata algae is a crescent-shaped cell with an average length of 5-10 $\mu \mathrm{m}$. An increase in the $\mathrm{pH}$ was globally observed in both tests for a given concentration between the beginning and the end of the exposure in accordance with classical measures with

Table 2. Average percentage inhibition of cell growth $\left(I_{A_{\mathrm{i}}}\right)$ and growth rate $\left(I_{\mu \mathrm{i}}\right)$ of the freshwater algae Pseudokirchneriella subcapitata exposed to MWNTs for $72 \mathrm{~h}$ : (a) preliminary test; (b) definitive test.

\begin{tabular}{|c|c|c|c|}
\hline & Nominal concentration of MWNTs $\left(\mathrm{mg} \mathrm{L}^{-1}\right)$ & $I_{\mathrm{Ai}}(\%)$ & $I_{\mu \mathrm{i}}(\%)$ \\
\hline \multirow[t]{6}{*}{ (a) } & 0 & 0 & 0 \\
\hline & 1 & 0 & 0 \\
\hline & 5 & 0 & 0 \\
\hline & 10 & 0 & 1 \\
\hline & 50 & 27 & 7 \\
\hline & 100 & 54 & 13 \\
\hline \multirow[t]{8}{*}{ (b) } & 0 & 0 & 0 \\
\hline & 10 & 13 & 2 \\
\hline & 22 & 26 & 6 \\
\hline & 48 & 54 & 14 \\
\hline & 105 & 90 & 44 \\
\hline & 230 & 99 & 73 \\
\hline & 500 & 100 & 82 \\
\hline & 1000 & 100 & 102 \\
\hline
\end{tabular}


Table 3. Measured $\mathrm{pH}$ and $\mathrm{O}_{2}$ concentrations in the preliminary test (a) and in the definitive test (b) of the exposure of the freshwater algae Pseudokirchneriella subcapitata to MWNTs.

\begin{tabular}{|c|c|c|c|c|c|}
\hline & \multirow{2}{*}{$\begin{array}{l}\text { Nominal Concentration } \\
\text { of MWNTs } \mathrm{mg} \mathrm{L}^{-1}\end{array}$} & \multicolumn{2}{|c|}{$\mathrm{pH}$} & \multicolumn{2}{|c|}{ Dissolved $\mathrm{O}_{2}\left(\mathrm{mg} \mathrm{L}^{-1}\right)$} \\
\hline & & $T_{0}$ & $T_{72 \mathrm{~h}}$ & $T_{0}$ & $T_{72 \mathrm{~h}}$ \\
\hline \multirow[t]{6}{*}{ (a) } & 0 & 7.89 & 7.91 & 9.0 & 9.6 \\
\hline & 1 & 7.92 & 9.42 & 9.1 & 9.7 \\
\hline & 5 & 7.94 & 9.29 & 9.1 & 9.5 \\
\hline & 10 & 7.94 & 9.40 & 9.0 & 9.7 \\
\hline & 50 & 7.95 & 8.83 & 9.0 & 9.4 \\
\hline & 100 & 7.96 & 8.62 & 9.0 & 9.3 \\
\hline \multirow[t]{8}{*}{ (b) } & 0 & 7.96 & 7.98 & 8.8 & 8.8 \\
\hline & 10 & 7.90 & 8.90 & 9.0 & 8.9 \\
\hline & 22 & 7.91 & 8.60 & 9.0 & 8.8 \\
\hline & 48 & 7.89 & 8.30 & 9.0 & 8.7 \\
\hline & 105 & 7.90 & 8.04 & 9.0 & 8.6 \\
\hline & 230 & 7.91 & 7.97 & 9.0 & 8.5 \\
\hline & 500 & 7.96 & 7.97 & 9.0 & 8.5 \\
\hline & 1000 & 8.03 & 7.99 & 8.9 & 8.4 \\
\hline
\end{tabular}

algae (Table 3). This may be associated with consumption of the dissolved $\mathrm{CO}_{2}$ due to the growth of algae. Above $230 \mathrm{mg} \mathrm{L}{ }^{-1}$ of MWNTs, $\mathrm{pH}$ becomes stable during $72 \mathrm{~h}$. Evolution of dissolved $\mathrm{O}_{2}$ concentration during $72 \mathrm{~h}$ is not significant.

Table 4 highlights the decrease of Fe concentrations under MWNT exposure. 11.65 $\mu \mathrm{gg}^{-1}$ of $\mathrm{Fe}$ was measured in the presence of $\mathrm{Fe}$ and the absence of MWNTs, whereas no Fe was measured in the presence of both Fe and MWNTs. Zn concentrations also decreased in less proportion from $3.4 \mu \mathrm{g} \mathrm{L}^{-1}$ in the presence of $\mathrm{Fe}$ and the absence of MWNTs. Other elements were not affected by the treatment. The results of cell growth and growth rate inhibition without Fe check the effect of iron deficiency and demonstrate iron absorption by MWNTs. Indeed, both inhibition rates lead to $88.88 \%$ and to $57.22 \%$ in Fe-deprivation medium, whereas there is no inhibition of growth in presence of Fe.

\section{D. magna acute immobilization test}

The study was performed in compliance with the following quality criteria: (1) the immobilization in the control did not exceed $10 \%$ at the end of the test, (2) daphnids in the control were not trapped at the surface of the water, and (3) the dissolved oxygen concentration remained above $3 \mathrm{mg} \mathrm{L}^{-1}$ over the test period. No immobilization

Table 4. Measured metal species in $\mu \mathrm{g} \mathrm{kg}^{-1}$ using ICP-MS in alga medium in presence or absence of Fe and MWNTs.

\begin{tabular}{|c|c|c|c|c|c|c|c|c|c|c|}
\hline & & & B & $\mathrm{Mn}$ & $\mathrm{Fe}$ & Co & $\mathrm{Ni}$ & $\mathrm{Cu}$ & $\mathrm{Zn}$ & Mo \\
\hline Alga medium & $-\mathrm{Fe}$ & -MWNTs & 53.2 & 110.4 & $<1$ & $<1$ & $<1$ & $<1$ & 1.6 & 2.7 \\
\hline Alga medium & $+\mathrm{Fe}$ & -MWNTs & 39.5 & 122.8 & 11.6 & $<1$ & $<1$ & $<1$ & 3.4 & 3.3 \\
\hline Alga medium & $+\mathrm{Fe}$ & +MWNTs & 43.8 & 94.8 & $<1$ & $<1$ & $<1$ & $<1$ & $<1$ & 3.2 \\
\hline
\end{tabular}

ICP-MS: Inductively coupled plasma-mass spectrometry.

B: Boron - Mn: Manganese - Fe: Iron - Co: Cobalt - Ni: Nickel - Cu: Copper - Zn: Zinc - Mo: Molybdenum.

Measured values correspond to mean value from two replicates. 
Table 5. Dissolved $\mathrm{O}_{2}$ and $\mathrm{pH}$ measured at the beginning $\left(T_{0}\right)$ and at the end $\left(T_{48} \mathrm{~h}\right)$ of the exposure of Daphnia magna to MWNTs for the definitive test of immobilization.

\begin{tabular}{lccccc}
\hline \multirow{2}{*}{$\begin{array}{l}\text { MWNT Concentrations } \\
\mathrm{mg} \mathrm{L}^{-1}\end{array}$} & \multicolumn{2}{c}{$\mathrm{pH}$} & & \multicolumn{2}{c}{ Dissolved $\mathrm{O}_{2}\left(\mathrm{mg} \mathrm{L}^{-1}\right)$} \\
\cline { 2 - 3 } \cline { 5 - 6 } & $T_{0}$ & $T_{48 \mathrm{~h}}$ & & $T_{0}$ & $T_{48 \mathrm{~h}}$ \\
\hline 0 & 7.95 & 7.77 & 8.4 & 8.1 \\
100 & 7.95 & 7.73 & 8.5 & 8.3 \\
\hline
\end{tabular}

effect is observed, regardless of the MWNT concentration in both tests, at 24 and $48 \mathrm{~h}$. After the 24-h and 48-h test periods, the actual concentrations inhibiting the mobility of daphnids, i.e. $\mathrm{EC}_{50}-24 \mathrm{~h}$ and $\mathrm{EC}_{50}-48 \mathrm{~h}$, were estimated to be both higher than $100 \mathrm{mg} \mathrm{L}^{-1}$. Neither $\mathrm{pH}$ nor concentrations of dissolved $\mathrm{O}_{2}$ were impacted in the presence of $100 \mathrm{mg} \mathrm{L}^{-1}$ of MWNTs during $48 \mathrm{~h}$ (Table 5). The appearance of the test suspensions was visually checked at the beginning and at the end of the test: as flasks were continuously maintained under axial rotation by use of a cylindrical roller device, MWNTs remained in suspension.

\section{D. magna reproduction test}

The study was performed in compliance with the quality criteria: (1) the mortality in the controls (parent females) did not exceed $20 \%$ at the end of the test, and (2) the average cumulative number of living young produced per surviving parent female was higher than 60 in the controls at the end of the test. The percentage of inhibition of the reproduction was dose dependent (Table 6). Inhibition percentage ranged from 0.30 (to $10 \mathrm{mg} \mathrm{L}^{-1}$ of MWNTs) to $21.06 \%$ (at $100 \mathrm{mg} \mathrm{L}^{-1}$ of MWNTs). The $\mathrm{EC}_{50}$ value was $317.75 \mathrm{mg} \mathrm{L}^{-1}$, and LOEC and NOEC were 100 and $47 \mathrm{mg} \mathrm{L}^{-1}$, respectively. After filling and between each renewal, there was sedimentation of the MWNTs at the bottom of the flasks.

\section{Fish acute toxicity test (D. rerio)}

The study was performed in compliance with the following quality criteria: (1) the mortality in the control did not exceed $10 \%$ at the end of the test; (2) the concentration of dissolved oxygen in the test vessels remained above $60 \%$ of the air saturation value at the end of the test; (3) the $\mathrm{pH}$ did not vary by more than 1 unit. The results indicated no mortality effect regardless of the MWNTs concentration in both tests and irrespective of exposure time, 24, 48, 72 or $96 \mathrm{~h}$ (Table 7). $\mathrm{LC}_{50}$ were then higher than $100 \mathrm{mg} \mathrm{L}^{-1}$ at each time. $\mathrm{pH}$ (Table 7) and saturation in oxygen (Table 8 ) were stable both in the preliminary and

Table 6. Results of the Daphnia magna reproduction test. Percentage of inhibition of reproduction measurement after 21 days of exposure.

\begin{tabular}{lcrrrrr}
\hline MWNT concentrations $\left(\mathrm{mg} \mathrm{L}^{-1}\right)$ & \multicolumn{1}{c}{5} & \multicolumn{1}{c}{10} & \multicolumn{1}{c}{22} & \multicolumn{1}{c}{47} & 100 \\
\hline Mean & 193.70 & 197.67 & 193.11 & 186.40 & 169.70 & 152.90 \\
Standard deviation & 21.78 & 64.40 & 61.74 & 15.60 & 27.08 & 46.73 \\
\% Inhibition & - & 2.05 & 0.30 & 3.77 & 12.39 & 21.06 \\
\hline
\end{tabular}


Table 7. Measured pH in (a) preliminary test at the beginning $(0 \mathrm{~h})$ of the experiment and at the end of exposure ( $96 \mathrm{~h}$ ) and in (b) definitive test, each having a total exposure time of $24 \mathrm{~h}$ in fish experiment.

\begin{tabular}{|c|c|c|c|c|c|c|}
\hline \multirow[b]{2}{*}{ (a) } & \multirow[b]{2}{*}{ MWNT concentrations $\left(\mathrm{mg} \mathrm{L}^{-1}\right)$} & \multicolumn{2}{|c|}{$\mathrm{pH}$} & & & \\
\hline & & $\mathrm{Oh}$ & $96 \mathrm{~h}$ & & & \\
\hline \multirow{3}{*}{ (b) } & $\begin{array}{c}0 \\
1 \\
35 \\
50 \\
100\end{array}$ & $\begin{array}{l}7.81 \\
7.76 \\
7.83 \\
7.86 \\
7.85\end{array}$ & $\begin{array}{l}7.81 \\
7.81 \\
7.83 \\
7.87 \\
7.87\end{array}$ & $\mathrm{pH}$ & & \\
\hline & MWNT concentrations ( $\mathrm{mg} \mathrm{L}^{-1}$ ) & $0 \mathrm{~h}$ & $24 \mathrm{~h}$ & $48 \mathrm{~h}$ & $72 \mathrm{~h}$ & $96 \mathrm{~h}$ \\
\hline & $\begin{array}{c}0 \\
100\end{array}$ & $\begin{array}{l}7.76 \\
7.82\end{array}$ & $\begin{array}{l}7.77 \\
775\end{array}$ & $\begin{array}{l}7.46 \\
776\end{array}$ & 7.78 & $\begin{array}{l}7.83 \\
7.85\end{array}$ \\
\hline
\end{tabular}

definitive tests. Thanks to the stirring device, it was observed that many of the MWNT particles remained in suspension within each tank.

\section{Amphibian (X. laevis) bioassays}

No mortality was observed until $72 \mathrm{~h}$ of exposure whatever the MWNT concentration. Very low mortality was observed from $50 \mathrm{mg} \mathrm{L}^{-1}$ at $96 \mathrm{~h}$ of exposure and was not significant compared to the negative control $\left(0 \mathrm{mg} \mathrm{L}^{-1}\right)$. $\mathrm{EC}_{50}$ was then estimated to be higher than $500 \mathrm{mg} \mathrm{L}^{-1}$.

Results of Xenopus exposure for 12 days in semi-static conditions indicated 20\% mortality at $50 \mathrm{mg} \mathrm{L}^{-1}$ of MWNTs. No mortality was observed at lower concentrations. Growth inhibition results (Figure 2) were significantly evidenced in larvae exposed to 25 (no growth of larvae) and $50 \mathrm{mg} \mathrm{L}^{-1}$ of MWNTs (four times less). MN induction in Xenopus larvae after 12 days of exposure to the referent genotoxic CP (Figure 3) was significant

Table 8. Measured $\mathrm{O}_{2}$ concentrations (a) in the preliminary test at the beginning of the experiment $(0$ h) and at the end of exposure ( $96 \mathrm{~h}$ ) and (b) in the definitive test.

\begin{tabular}{|c|c|c|c|c|c|c|}
\hline \multirow[b]{2}{*}{ (a) } & \multirow[b]{2}{*}{ MWNT concentrations $\left(\mathrm{mg} \mathrm{L}^{-1}\right)$} & \multicolumn{2}{|c|}{ Dissolved $\mathrm{O}_{2}\left(\mathrm{mg} \mathrm{L}^{-1}\right)$} & & & \\
\hline & & $0 \mathrm{~h}$ & $96 \mathrm{~h}$ & & & \\
\hline \multirow{6}{*}{ (b) } & \multirow[b]{2}{*}{ MWNT concentrations $\left(\mathrm{mg} \mathrm{L}^{-1}\right)$} & $\begin{array}{l}8.0 \\
8.3 \\
8.3 \\
8.1 \\
8.2\end{array}$ & $\begin{array}{l}9.2 \\
9.3 \\
9.2 \\
9.1 \\
9.1 \\
\text { Diss }\end{array}$ & $\mathrm{mg} \mathrm{L}^{-}$ & & \\
\hline & & $\mathrm{Oh}$ & $24 \mathrm{~h}$ & $48 \mathrm{~h}$ & $72 \mathrm{~h}$ & $96 \mathrm{~h}$ \\
\hline & 100 & 95 & 99 & 96 & 97 & 98 \\
\hline & 100 & 95 & 99 & 95 & 98 & 98 \\
\hline & 0 & 95 & 98 & 93 & 98 & 98 \\
\hline & 0 & 95 & 98 & 93 & 97 & 97 \\
\hline
\end{tabular}




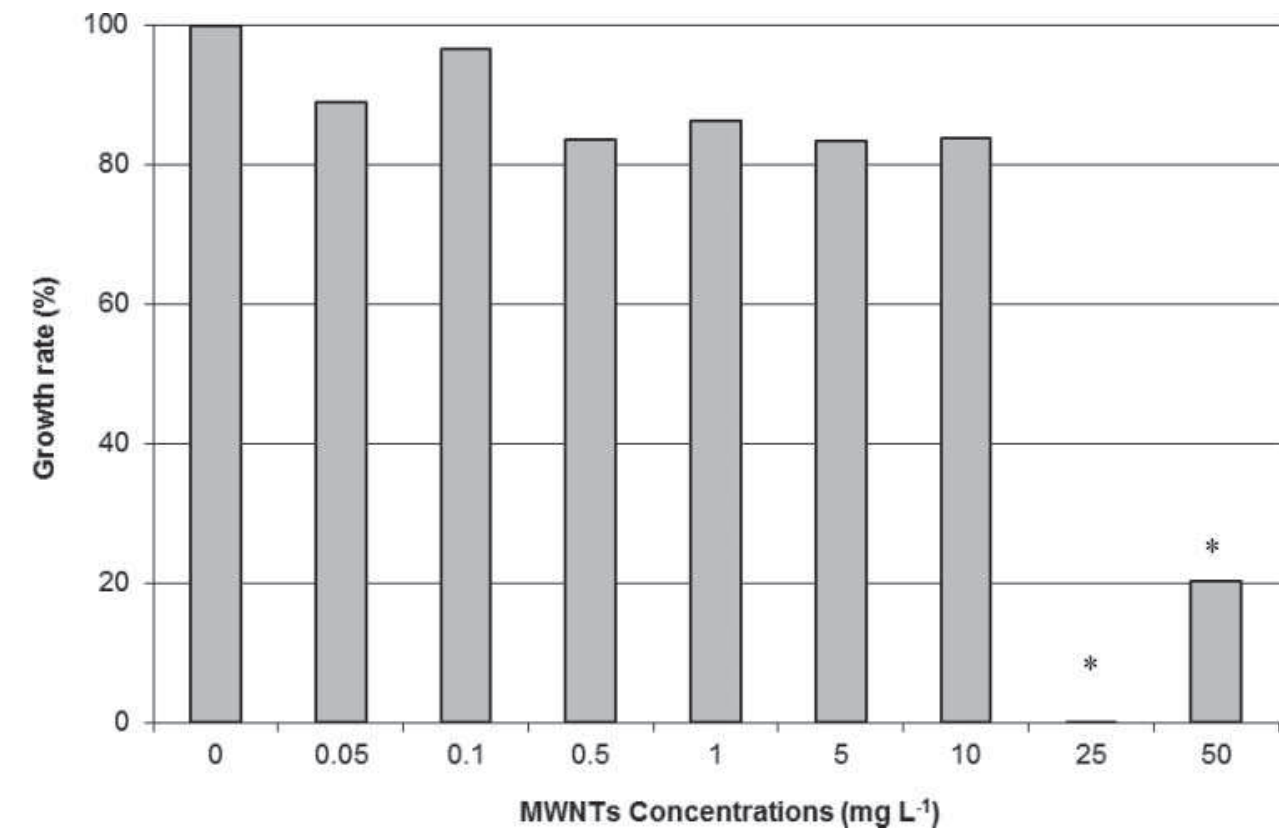

Figure 2. Growth inhibition measurement of Xenopus larvae after 12 days of semi-static exposure to MWNTs.

Note: *indicates a significant lower length compared to the control $\left(0 \mathrm{mg} \mathrm{L}^{-1}\right)$. Growth rate is calculated as a percentage based on the length measurement of larvae at the beginning of the exposure and at the end.

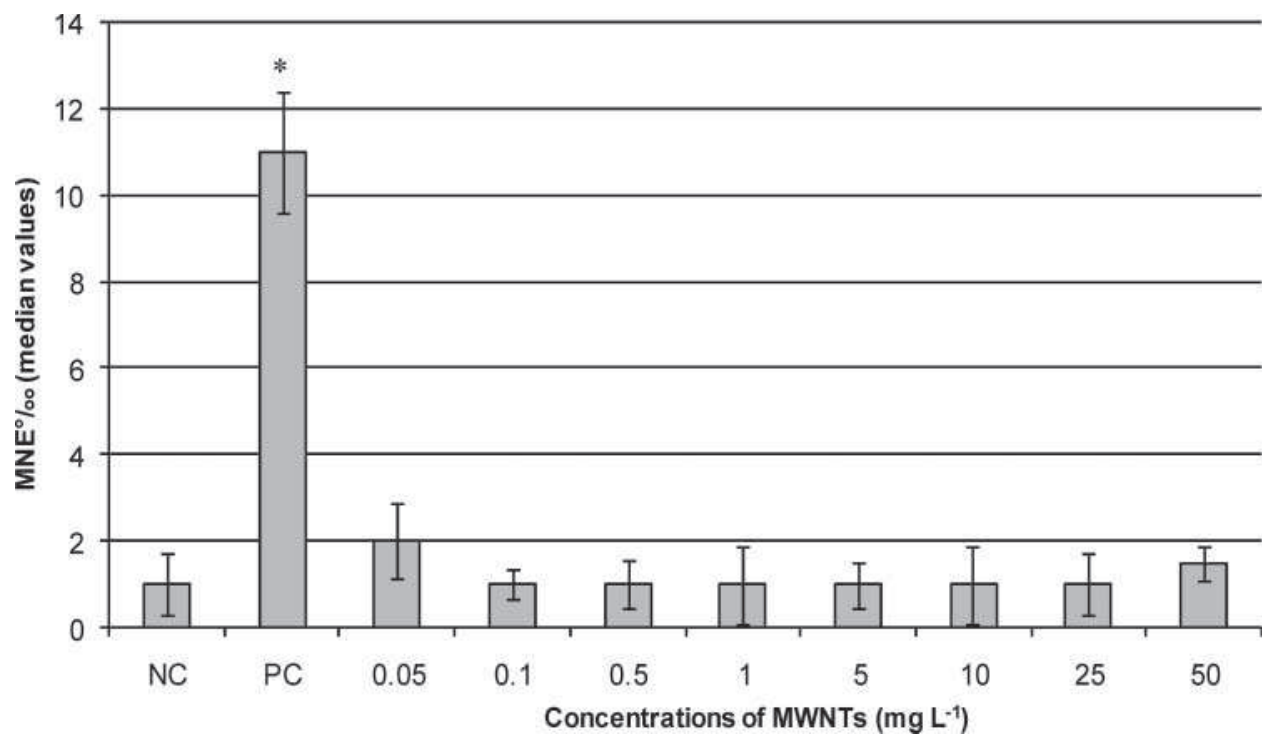

Figure 3. Micronucleus induction measurement (median \pm IC 95\%) in erythrocytes of Xenopus larvae after 12 days of semi-static exposure according to the concentration of MWNTs.

Note: *indicates a genotoxic condition compared to the negative control NC $\left(0 \mathrm{mg} \mathrm{L}^{-1}\right.$ of MWNTs).PC: Positive Control, Cyclophosphamide, genotoxic of reference to $20 \mathrm{mg} \mathrm{L}^{-1}$. MNE $/ 00$ : Micronucleated erythrocytes. 
Table 9. Measured $\mathrm{pH}$ values during the 12 days of exposure of Xenopus larvae to different concentrations of MWNTs. $\mathrm{pH}_{0 \mathrm{~h}}$ was measured just after the renewal of the exposure medium. $\mathrm{pH}_{24 \mathrm{~h}}$ was measured just before the renewal.

\begin{tabular}{lcc}
\hline MWNT concentrations $\left(\mathrm{mg} \mathrm{L}^{-1}\right)$ & $\mathrm{pH}_{0 \mathrm{~h}}$ & $\mathrm{pH}_{24 \mathrm{~h}}$ \\
\hline 0 & 8.00 & 7.31 \\
0.05 & 8.04 & 7.30 \\
0.1 & 8.04 & 7.26 \\
0.5 & 8.05 & 7.27 \\
1 & 8.14 & 7.22 \\
5 & 8.12 & 7.33 \\
10 & 8.27 & 7.19 \\
25 & 8.14 & 7.43 \\
50 & 8.09 & 7.29 \\
\hline
\end{tabular}

compared to the NC. This result validates the bioassay. The results of $\mathrm{MN}$ induction in larvae exposed to MWNTs indicated no genotoxicity compared to the NC group. Median values were distributed without MWNTs' dose-effect relation. $\mathrm{pH}$ values (Table 9) were slightly lower after $24 \mathrm{~h}$ of exposure $\left(\mathrm{pH}_{24} \mathrm{~h}\right)$ compared to just after the renewal of the exposure medium $\left(\mathrm{pH}_{0 \mathrm{~h}}\right.$ ). It may be in relation to the excretion process of larvae for $24 \mathrm{~h}$ and the acidification of the exposure media. There was no $\mathrm{pH}$ modification in relation to MWNT concentrations. Metals were dosed in water exposure in the presence or absence of $50 \mathrm{mg} \mathrm{L}^{-1}$ of MWNTs, without larvae, after $24 \mathrm{~h}$ of contact (Table 10). $12.8 \pm 0.6 \mu \mathrm{g}$ $\mathrm{L}^{-1}$ of Mo and $131.5 \pm 5.4 \mu \mathrm{g} \mathrm{L}^{-1}$ of $\mathrm{Al}$ were measured in medium in the presence of MWNTs, whereas concentration of Fe was under the quantification limit $\left(<10 \mu \mathrm{g} \mathrm{L}^{-1}\right)$.

\section{Discussion}

The aim of the present work is not to compare the biological effects between different biological models but to contribute to a better understanding of the ecotoxicity of CNTs and their environmental exposure assessment to provide valuable insight into likely exposure scenarios at different levels of the trophic chain. Synthetic results of the biological effects in organisms after MWNT exposure are presented in Table 11. The results are as follows: no toxicity in activated sludge (bacteria) at $500 \mathrm{mg} \mathrm{L}^{-1}$ of MWNTs, no acute toxicity in fish and daphnia up to $100 \mathrm{mg} \mathrm{L}^{-1}$ of MWNTs, inhibition of growth in amphibian larvae at $25 \mathrm{mg} \mathrm{L}^{-1}$ of MWNTs, and a notable effect at high concentrations of MWNTs with the growth inhibition test in algae $\left(\mathrm{EC}_{50}=120 \mathrm{mg} \mathrm{L}^{-1}\right.$ and $\left.\mathrm{NOEC}=10 \mathrm{mg} \mathrm{L}^{-1}\right)$.

Observed toxicity in this present work is in accordance with much of the data published in the literature relative to the potential toxicity of raw CNTs in aquatic organisms.

Table 10. Measured metal species (Al, Fe, Mo) in $\mu \mathrm{g} \mathrm{L}^{-1}$ using ICP-AES in amphibian mediums in the presence or absence of $50 \mathrm{mg} \mathrm{L}^{-1}$ of MWNT after $24 \mathrm{~h}$ of contact.

\begin{tabular}{lccc}
\hline & Fe & Mo & Al \\
\hline- MWNTs & $<10 \mu \mathrm{g} \mathrm{L}^{-1}$ & $<10 \mu \mathrm{g} \mathrm{L}^{-1}$ & $<50 \mu \mathrm{g} \mathrm{L}^{-1}$ \\
+ MWNTs & $<10 \mu \mathrm{g} \mathrm{L}^{-1}$ & $12.80 \pm 0.58 \mu \mathrm{g} \mathrm{L}^{-1}$ & $131.50 \pm 5.36 \mu \mathrm{g} \mathrm{L}^{-1}$ \\
\hline
\end{tabular}

Fe: Iron - Mo: Molybdenum - Al: aluminum.

Calculated values correspond to mean value from 4 replicates ( \pm standard error).

Quantification limit $(\mathrm{QL})$ is $10 \mu \mathrm{g} \mathrm{L}^{-1}$ for Fe and Mo, and $50 \mu \mathrm{g} \mathrm{L}^{-1}$ for Al. 


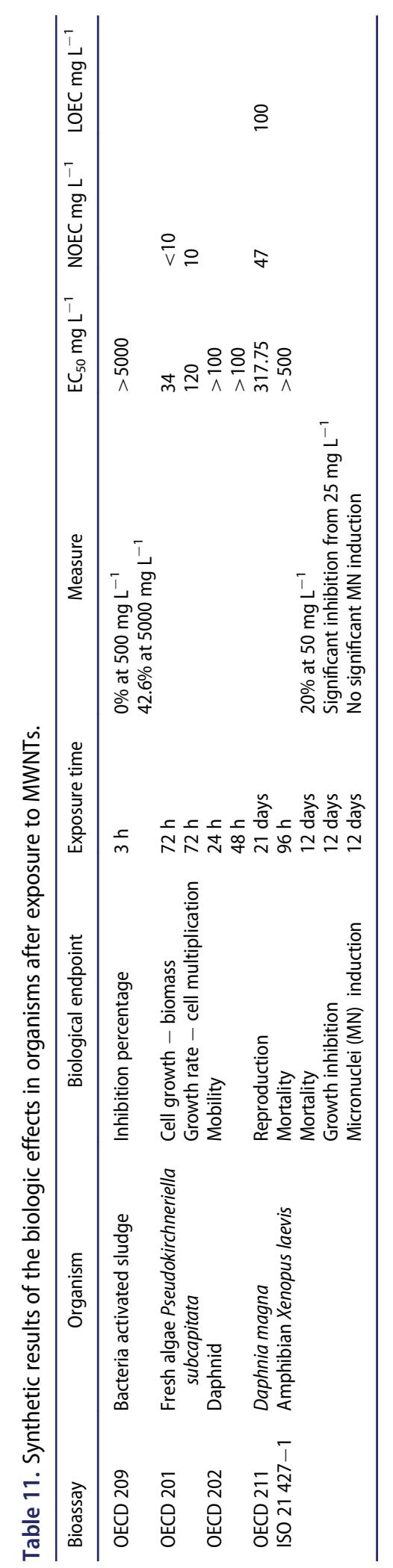


An LOEC of $10 \mathrm{mg} \mathrm{L}^{-1}$ was observed in daphnia (Roberts et al. 2007), in marine copepod (Templeton et al. 2006) and in amphibians (Mouchet et al. 2008). Zhu and collaborators (Zhu et al. 2009) calculated $\mathrm{EC}_{50}$ to 8.72 and $1.30 \mathrm{mg} \mathrm{L}^{-1}$ for immobilization of daphnia exposed to raw SWNTs and MWNTs, respectively, and to 22.57 and $2.42 \mathrm{mg} \mathrm{L}^{-1}$ for mortality exposed to raw SWNTs and MWNTs, respectively. Kennedy and collaborators (Kennedy et al. 2008) calculated $\mathrm{EC}_{50}$ for mortality after $48 \mathrm{~h}$ of raw MWNTs exposure in daphnia at $50.9 \mathrm{mg} \mathrm{L}^{-1}$. No toxicity was evidenced for hydra and crustaceans up to $100 \mathrm{mg} \mathrm{L}^{-1}$ of raw SWNTs (Blaise et al. 2008), whereas toxicity to algae exposed to SWNTs was observed at $10 \mathrm{mg} \mathrm{L}^{-1}$. Cheng, Flahaut, and Cheng (2007) observed hatching delay in fish eggs exposed to $120 \mathrm{mg} \mathrm{L}^{-1}$ of raw SWNTs and $240 \mathrm{mg} \mathrm{L}^{-1}$ of raw DWNTs. Neither mortality nor growth inhibition was observed in urodele amphibian larvae up to $1 \mathrm{~g} \mathrm{~L}^{-1}$ of raw DWNTs (Mouchet et al. 2007), whereas mortality was observed at $50 \mathrm{mg}$ $\mathrm{L}^{-1}$ and growth inhibition from $10 \mathrm{mg} \mathrm{L}^{-1}$ in anuran amphibian larvae exposed to raw DWNTs (Mouchet et al. 2008, 2011) as well as growth inhibition at $50 \mathrm{mg} \mathrm{L}^{-1}$ for raw MWNTs exposure (Mouchet et al. 2010). Kahru and Dubourguier (2011) calculated on the basis of 34 median values a $\mathrm{L}(\mathrm{E}) \mathrm{C}_{50}$ between 1 and $10 \mathrm{mg} \mathrm{L}^{-1}$ for SWNTs and MWNTs $\left(\mathrm{L}(\mathrm{E}) \mathrm{C}_{50}\right.$ derived from 77 individual values. The majority of the published results indicate that exposure to CNTs generally leads to biological disorder at different levels but usually above unrealistic concentrations of $10 \mathrm{mg} \mathrm{L}^{-1}$. In surface water in Europe, for the simulation results of the predicted environmental concentrations, Gottschalk et al. (2009) indicated lower CNTs concentrations, with $0.004 \mathrm{ng} \mathrm{L}^{-1}$ (most frequent value) and $0.0035 \mathrm{ng} \mathrm{L}^{-1}$ as the range of the lower quantile and $0.021 \mathrm{~g} \mathrm{~L}^{-1}$ as the upper quantile. Nevertheless, it could be hypothesized that CNT concentrations accumulate into the environment over time.

Toxicity obtained from algae in the present work appears to be in relation to the effect of Fe deficiency on algal growth. Indeed, algal growth experiments in the absence of iron indicated $88.8 \%$ of cell growth inhibition (biomass) and $57.2 \%$ of growth rate inhibition (cell multiplication) compared to the absence of inhibition when iron was present. Moreover, among the 8 micro-nutrients that are present in the algal culture medium (boron, manganese, iron, cobalt, nickel, copper, zinc, and molybdenum), iron is strongly removed by the MWNTs from the filtrated culture medium $\left(<1 \mu \mathrm{g} \mathrm{kg}^{-1}\right)$. When compared to the initial algal medium in which iron concentration is $11.65 \mu \mathrm{g} \mathrm{kg}^{-1}$, this leads to suspect iron adsorption by MWNTs. Iron ion adsorption has already been demonstrated in chemical studies using different types of CNTs (Li et al. 2009). In contrast to the present growth inhibition of $P$. subcapitata due to iron deprivation, Schwab et al. (2011) indicated that observed inhibition of C. vulgaris and P. subcapitata is in relation to light masking by CNTs, which can adhere to algal surfaces and hence restrict light accessibility to the cells, resulting in the inhibition of growth. Long et al. (2012) indicated that their MWNTs significantly inhibited the algal growth of Chlorella sp. with a negligible contribution of metal catalyst residues in the MWNTs and nutrient elements adsorbed by MWNTs. These authors hypothesize that the toxicity of algae could mainly be explained by the combined effects of oxidative stress, agglomerations and physicals interactions, and shading effects, with the quantitative contributions from these mechanisms depending on the MWNT size and concentration. In any case, comparison of results between these different works must be limited because of the diversity of studied CNTs. Nevertheless, Verneuil et al. (2014) indicated that only direct exposure to $50 \mathrm{mg} \mathrm{L}^{-1}$ of MWNTs (the same type of 
MWNTs as in the present study) led to growth inhibition of Nitzschia palea after $48 \mathrm{~h}$ and suggested that EPS (extracellular polymeric substances) provide considerable protection against MWNTs, without alteration of the photosynthesis.

Concerning the absence of genotoxicity in erythrocytes of Xenopus larvae, the present results are in agreement with the previous ones obtained on amphibian larvae in the same conditions of exposure to MWNTs (Mouchet et al. 2010) and DWNTs (Mouchet et al. 2007, 2008). The majority of the time, if acute and chronic toxicities are generally observed after CNTs exposure of different biological models, genotoxicity, especially via micronucleus induction mechanism, is not demonstrated. Kim et al. (2011) indeed obtained no genotoxicity of raw MWNTs according to OECD test guidelines 471 (bacterial reverse mutation test), 473 (in vitro chromosome aberration test with and without S9), and 474 (in vivo micronuclei test). Di Sotto et al. (2009) and Szendi and Varga (2008) also reported that MWNTs had no mutagenic effect in bacteria systems. In the same way, Wirnitzer et al. (2008) indicated no genotoxicity of raw MWNTs testing for chromosome aberrations in V79 cells and for gene mutations in the Salmonella microsome test. Nevertheless, genotoxic effects may be produced either by direct interaction of particles with genetic material or by secondary damage from particle-induced reactive oxygen species. In this context, some authors demonstrated oxidative stress by MWNTs (Reddy et al. 2010; Srivastava et al. 2011), and, for example, in Xenopus larvae after MWNT exposure (Saria et al. 2014).

Exposure media for the different organisms would play a role in the observed toxicity of the present work. Nevertheless, characterizations of the MWNT suspension in exposure medium do not appear essential to place it in relation with biological effects because they are observed at very high and unrealistic concentrations. The effects obtained in the present work are globally weakly marked, probably in relation with the MWNTs' limited bioavailability in the water column for organisms because of CNTs' sedimentation at the bottom of containers. As displayed in Figure 1, raw MWNTs appeared as large rather spherical agglomerates of bundles without free or isolated nanotubes. Observed effects in organisms may be in connection with exposure to these agglomerates inducing respiratory and/or intestinal clogging in relation with their absorption and not necessarily related to the intrinsic effects of CNTs (Mouchet et al. 2010 and 2011; Petersen et al. 2011). This result is also in accordance with the observation of CNTs in the guts of aquatic organisms such as Lumbriculus variegatus (Petersen, Huang, and Weber 2008), Arenicola marina (Galloway et al. 2010), D. magna (Zhu et al. 2009), Hyalella azteca, Leptocheirus plumulosus, and Ceriodaphnia dubia (Kennedy et al. 2009). Li and Huang (2011) describe the ingestion of CNTs in C. dubia followed by excretion in exposure media. Many of these studies tend to highlight that ingested CNTs by organisms may enter the ecological pyramid via their move up through the food chain. Moreover, excreted CNTs may contribute to maintaining a pressure contamination of CNTs in media.

Nevertheless, a few $\mu \mathrm{g} \mathrm{L}^{-1}$ of Mo and $\mathrm{Al}$ (and no $\mathrm{Fe}$ ) were measured in the water medium of amphibian exposure after $24 \mathrm{~h}$ containing the higher concentration of MWNTs $\left(50 \mathrm{mg} \mathrm{L}^{-1}\right.$ ). It would suggest that they may contribute, especially $\mathrm{Al}$, to the toxicity observed in amphibians to high concentrations of MWNTs, although no genotoxicity was observed. This result encourages us to investigate the potential release of metal impurities at lower concentrations and in function of time in the different water exposures. 


\section{Conclusion}

The present knowledge concerning the ecotoxic effects of CNTs is rather limited and deserves to be documented more extensively. First, the ecotoxicological hazard assessment needs approaches and measurement tools using standardized test methods. Then, adaptation of well-known protocols is necessary. This work is thus a contribution to the assessment of the potential ecotoxicity of CNTs within the aquatic compartment; it could be helpful for regulatory purposes. The results indicate that MWNT effects are weakly marked and expressed at unrealistic nominal concentrations (approximately $10 \mathrm{mg} \mathrm{L}^{-1}$ ), in relation with probable MWNT ingestion. Considering their increasing use in commercial products, this study emphasizes the need to further study their ecotoxicity and highlights that assessing the risks of CNTs requires a better understanding of their toxicity, bioavailability, and behavior in relation with their intrinsic physicochemical properties.

\section{Acknowledgments}

The authors acknowledge Annie Perrault and Floriane Bourdiol for their technical help. Thanks to the Groupement de Recherche de Lacq (ARKEMA) for MWNTs suspensions and technical help. We are also indebted to Michel Lagoin (Universite Paul Sabatier, Toulouse, France) for reviewing the English version of the manuscript and to the language services of Elsevier.

\section{Disclosure statement}

Part of this research has been developed in the framework of the French collaborative laboratory NAUTILE (Nanotubes et Ecotoxicologie), which is the first public/private joint laboratory dedicated to the study of the ecotoxicological impact of CNTs in the aquatic environment. The framework agreement was signed by (1) Arkema France, (2) Centre National de la Recherche Scientifique (CNRS), (3) Institut National Polytechnique de Toulouse (INPT), and (4) Université Paul Sabatier (UPS) of Toulouse in September 2010. The authors declare no competing financial interests or conflict of interest.

\section{References}

Blaise, C., F. Gagné, J.F. Férard, and P. Eullafroy. 2008. "Ecotoxicity of Selected Nano-materials to Aquatic Organisms.” Environmental Toxicology 23 (5): 591-598.

Cheng, J., E. Flahaut, and S.H. Cheng. 2007. "Effect of Carbon Nanotubes on Developing Zebrafish (Danio rerio) Embryos." Environmental Toxicology and Chemistry 26 (4): 708-716.

Crane, M., R.D. Handy, J. Garrod, and R. Owen. 2008. "Ecotoxicity Test Methods and Environmental Hazard Assessment for Engineered Nanoparticles.” Ecotoxicology 17: 421-437.

Di Sotto, A., M. Chiaretti, G.A. Carru, S. Bellucci, and G. Mazzanti. 2009. "Multi-walled Carbon Nanotubes: Lack of Mutagenic Activity in the Bacterial Reverse Mutation Assay.” Toxicology Letters 184 (3): 192-197.

Eklund, P., P. Ajayan, R. Blackmon, A.J. Hart, J. Kong, B. Pradhan, A. Rao, and A. Rinzler. 2007. International Assessment of Research and Development of Carbon Nanotube Manufacturing and Applications. Baltimore, MD: World Technology Evaluation Center. http://www.wtec.org/cnm/ CNM_final_report.pdf.

EN ISO 6341. 1996. "Water Quality - Determination of the Inhibition of Mobility of Daphnia magna Straus (Cladocera, Crustacea) - Acute Toxicity Test.” Geneva: International Organization for Standardization. 
EN ISO 7346. 1998. "Water Quality - Determination of the Acute Lethal Toxicity of Substances to a Freshwater Fish [Brachydanio rerio Hamilton-Buchanan (Teleostei, Cyprinidae)]. Part 1: Static Method. Part 2: Semi-static Method. Part 3: Flow-Through Method.” Geneva: International Organization for Standardization.

EN ISO 8692. 2004. "Water Quality - Fresh Water Algal Growth Inhibition Test with Unicellular Green Algae.” Commission Regulation (EC) No 440/2008 of 30 May 2008. Geneva: International Organization for Standardization.

ENV/JM/MONO 13/REV. 2008. "Environment Directorate - Joint Meeting of the Chemicals Committee and the Working Party on Chemicals, Pesticides, and Biotechnologies Series on the Safety Manufactured Nanomaterials." No. 6. List of Manufactured Nanomaterials and List of Endpoints for Phase One of the OECD Testing Programme JT03248749. Unclassified, 07-Jul-2008. 1-13. Paris: Organization for Economic Co-operation and Development (OECD).

EU 2008. "Regulation EC No 1272/2008 of the European Parliament and of the Council of 16 December 2008 on Classification, Labelling and Packaging of Substances and Mixtures, Amending and Repealing Directives 67/548/EEC and 1999/45/EC, and Amending Regulation (EC) No 1907/2006." Official Journal of the European Union L353: 1355.

Galloway, T., C. Lewis, I. Dolciotti, B.D. Johnston, J. Moger, and F. Regoli. 2010. "Sublethal Toxicity of Nano-titanium Dioxide and Carbon Nanotubes in a Sediment Dwelling Marine Polychaete." Environmental Pollution 158: 1748-1755.

Gottschalk, F., T. Sonderer, R. Scholz, and B. Nowack. 2009. "Modeled Environmental Concentrations of Engineered Nanomaterials ( $\mathrm{TiO}_{2}, \mathrm{ZnO}, \mathrm{Ag}, \mathrm{CNT}$, Fullerenes) for Different Regions." Environmental Science and Technology 43: 9216-9222.

Guadagnini, R., B. Halamoda Kenzaoui, L. Cartwright, G. Pojana, Z. Magdolenova, D. Bilanicova, M. Saunders, et al. 2013. "Toxicity Screenings of Nanomaterials: Challenges Due to Interference with Assay Processes and Components of Classic In Vitro Tests.” Nanotoxicology (Supplement 1) 9: 13-24. doi:10.3109/17435390.2013.829590

Iijima, S. 1991. "Helical Microtubules of Graphitic Carbon." Nature 354: 56-58.

ISO. 2006. ISO International Standard. Water Quality - Evaluation of Genotoxicity by Measurement of the Induction of Micronuclei - Part 1: Evaluation of Genotoxicity Using Amphibian Larvae. ISO 21427-1, ICS: 13.060.70. Geneva: International Organization for Standardization.

Kahru, A., H.C. Dubourguier, I. Blinova, A. Ivask, and K. Kasemets. 2008. "Biotests and Biosensors for Ecotoxicology of Metal Oxide Nanoparticles: A Mini Review.” Sensors 8: 5153-517.

Kahru, A., and H.C. Dubourguier. 2011. "From Ecotoxicology to Nanoecotoxicology." Toxicology 269 (2-3): 105-119.

Kennedy, A.J., J.C. Gunter, M.A. Chappell, J.D. Goss, M.S. Hull, R.A. Kirgan, and J.A.A. Steevens. 2009. "Influence of Nanotube Preparation in Aquatic Bioassays." Environmental Toxicology and Chemistry 28 (9): 1930-1938.

Kennedy, A.J., M.S. Hull, J.A. Steevens, K.M. Dontsova, M.A. Chappell, J.C. Gunter, and C.A. Weiss. 2008. "Factors Influencing the Partitioning and Toxicity of Nanotubes in the Aquatic Environment." Environmental Toxicology and Chemistry 27 (9): 1932-1941.

Kim, J.S., K. Lee, Y.H. Lee, H.S. Cho, K.H. Kim, K.H. Choi, S.H. Lee, K.S. Song, C.S. Kang, and I.J. Yu. 2011. "Aspect Ratio Has No Effect on Genotoxicity of Multi-wall Carbon Nanotubes." Archives of Toxicology 85 (7): 775-86.

Kostarelos, K., A. Bianco, and M. Prato. 2009. "Promises, Facts and Challenges for Carbon Nanotubes in Imaging and Therapeutics." Nature Nanotechnology 4 (10): 627-633.

Li, H.B., L.K. Pan, Y. Zhang, and Z. Sun. 2009. "Ferric Ion Adsorption and Electrode Sorption by Carbon Nanotubes and Nanofibres Films.” Water Science and Technology 59 (8): 1657-1663.

Li, M., and C.P. Huang. 2011. "The Responses of Ceriodaphnia dubia Toward Multi-walled Carbon Nanotubes: Effect of Physical-Chemical Treatment.” Carbon 49: 1672-1679.

Long, Z., J. Ji, K. Yang, D. Lin, and F. Wu. 2012. "Systematic and Quantitative Investigation of the Mechanism of Carbon Nanotubes' Toxicity Toward Algae.” Environmental Science and Technology 46 (15): 8458-8466. 
Mouchet, F., P. Landois, V. Datsyuk, P. Puech, E. Pinelli, E. Flahaut, and L. Gauthier. 2011. "Use of the International Amphibian Micronucleus Standardized Procedure (ISO 21427-1) for In Vivo Evaluation of Double-Walled Carbon Nanotubes Toxicity and Genotoxicity in Water." Environmental Toxicology 26 (2): 136-145.

Mouchet, F., P. Landois, E. Flahaut, E. Pinelli, and L. Gauthier. 2007. "Assessment of the Potential In Vivo Ecotoxicity of Double-Walled Carbon Nanotubes (DWNTs) in Water, Using the Amphibian Ambystoma mexicanum." Nanotoxicology 1 (2): 149-156.

Mouchet, F., P. Landois, P. Puech, E. Pinelli, E. Flahaut, and L. Gauthier. 2010. "CNTs Ecotoxicity in Amphibians: Assessment of Multi-walled Carbon Nanotubes (MWNT) and Comparison with Double-Walled Carbon Nanotubes (DWNT)." Special Focus Environmental Toxicity of Nanoparticles. Nanomedicine 5 (6): 963-974.

Mouchet, F., P. Landois, E. Sarreméjean, G. Bernard, P. Puech, E. Pinelli, E. Flahaut, and L. Gauthier. 2008. "Characterisation and In Vivo Ecotoxicity Evaluation of Double-Wall Carbon Nanotubes in Larvae of the Amphibian Xenopus laevis." Aquatic Toxicology 87: 127-137.

Nieuwkoop, P.D., and J. Faber. 1956. Normal Tables of Xenopus Laevis (Daudin). Amsterdam: North-Holland.

OECD (Organisation for Economic Co-operation and Development). 1984. "Activated Sludge, Respiration Inhibition Test.” Guideline N 209 for the Testing of Chemicals, Adopted April 4, 1984. Paris: Organisation for Economic Co-operation and Development.

OECD (Organisation for Economic Co-operation and Development). 1992. "Fish, Acute Toxicity Test." Guideline $\mathrm{N}^{\circ} 203$ for the Testing of Chemicals, Adopted 17 July 1992. Paris: Organisation for Economic Co-operation and Development.

OECD (Organisation for Economic Co-operation and Development). 2004. "Daphnia sp., Acute Immobilisation Test." Guideline 202 for the Testing of Chemicals, Adopted 13 April 2004. Paris: Organisation for Economic Co-operation and Development.

OECD (Organisation for Economic Co-operation and Development). 2006. "Freshwater Alga and Cyanobacteria, Growth Inhibition Test." Guideline 201 for the Testing of Chemicals, Adopted 23 March 2006. Paris: Organisation for Economic Co-operation and Development.

OECD (Organisation for Economic Co-operation and Development). 2008. "Daphnia magna, Reproduction Test." Guideline 211 for the Testing of Chemicals, Adopted: 3 October 2008. Paris: Organisation for Economic Co-operation and Development.

Petersen, E.J., Q. Huang, and W.J. Weber. 2008. "Ecological Uptake and Depuration of Carbon Nanotubes by Lumbriculus variegates.” Environmental Health Perspectives 116 (4): 496-500.

Petersen, E.J., L. Zhang, N. Mattison, D. O'Carroll, A.J. Whelton, N. Uddin, T. Nguyen, et al. 2011. "Potential Release Pathways, Environmental Fate, and Ecological Risks of Carbon Nanotubes." Environmental Science and Technology 45: 9837-9856.

Reddy, A.R., Y.N. Reddy, D.R. Krishna, and V. Himabindu. 2010. "Multi-wall Carbon Nanotubes Induce Oxidative Stress and Cytotoxicity in Human Embryonic Kidney (HEK293) Cells." Toxicology $272(1-3): 11-6$.

Roberts, A.P., A.S. Mount, B. Seda, J. Souther, R. Qiao, S. Lin, P.C Ke, A.M. Rao, and S.J. Klaine. 2007. "In Vivo Biomodification of Lipid Coated Carbon Nanotubes by Daphnia Magna." Environmental Science and Technology 41: 3025-3029.

Saria, R., F. Mouchet, A. Perrault, E. Flahaut, C. Laplanche, J.C. Boutonnet, E. Pinelli, and L. Gauthier. 2014. "Evaluation of Oxidative Stress and DNA Damage in Xenopus laevis Tadpoles Exposed to Multi-walled Carbon Nanotubes." Ecotoxicology and Environmental Safety. 06/2014; 107C: 22-29. doi: http://dx.doi.org/10.1016/j.ecoenv.2014.05.010.

Schwab, F., T.D. Bucheli, L.P. Lukhele, A. Magrez, B. Nowack, L. Sigg, and K. Knauer. 2011. “Are Carbon Nanotube Effects on Green Algae Caused by Shading and Agglomeration?" Environmental Science and Technology 45: 6136-6144.

Srivastava, R.K., A.B. Pant, M.P. Kashyap, V. Kumar, M. Lohani, L. Jonas, and Q. Rahman. 2011. "Multi-walled Carbon Nanotubes Induce Oxidative Stress and Apoptosis in Human Lung Cancer Cell Line-A549.” Nanotoxicology 5 (2): 195-207.

Stafiej, A., and K. Pyrzynska. 2007. "Adsorption of Heavy Metal Ions with Carbon Nanotubes.” Separation and Purification Technology 58(1): 49-52. doi:10.1016/j.seppur.2007.07.008. 
Szendi, K., and C. Varga. 2008. "Lack of Genotoxicity of Carbon Nanotubes in a Pilot Study." Anticancer Research 28: 349-352.

Templeton, R.C., P. Lee Ferguson, K.M. Washburn, W.A. Scrivens, and G.T. Chandler. 2006. "LifeCycle Effects of Single-Walled Carbon Nanotubes (SWNTs) on an Estuarine Meiobenthic Copepod." Environmental Science and Technology 40: 7387-7393.

Van der Zande, M., R. Junker, X.F. Walboomers, and J.A. Jansen. 2011. "Carbon Nanotubes in Animal Models: A Systematic Review on Toxic Potential.” Tissue Engineering Part B Rev 17 (1): $57-69$.

Verneuil, L., J. Silvestre, F. Mouchet, E. Flahaut, J.C. Boutonnet, F. Bourdiol, T. Bortalomiol, D. Baque, L. Gauthier, and E. Pinelli. 2014. "Multi-walled Carbon Nanotubes, Natural Organic Matter and the Benthic Diatom Nitzschia palea: "A Sticky Story“.” Nanotoxicology. [Epub ahead of print] (doi:10.3109/17435390.2014.918202).

Wirnitzer, U., B. Herbold, M. Voetz, and J. Ragot. 2008. "Studies on the In Vitro Genotoxicity of Baytubes", Agglomerates of Engineered Multi-walled Carbon Nanotubes (MWCNT). Toxicity of Engineered Nanomaterials." Toxicological Letters 186 (3-8): 160-165.

Zhao, X., and R. Liu. 2012. "Recent Progress and Perspectives on the Toxicity of Carbon Nanotubes at Organism, Organ, Cell, and Biomacromolecule Levels." Environment International 40: $244-255$.

Zhu, X., L. Zhu, C. Yongsheng, and T. Shengyan. 2009. "Acute Toxicities of Six Manufactured Nanomaterial Suspensions to Daphnia magna.” Journal of Nanoparticle Research 11 (1): 67-75. 